\title{
Cellulophaga pacifica sp. nov.
}

Correspondence
Olga I. Nedashkovskaya
olganedashkovska@piboc.dvo.ru
or
olganedashkovska@yahoo.com

The genus Cellulophaga was proposed by Johansen et al. (1999) as a separate branch in the family Flavobacteriaceae, to comprise three species: Cellulophaga baltica and Cellulophaga fucicola, two agarolytic, yellow-orange-pigmented bacteria associated with the brown alga Fucus serratus, and Cellulophaga lytica, a common representative of coastal microbial communities that was formerly misclassified as [Cytophaga] lytica (Lewin, 1969; Reichenbach, 1989). The latter species was assigned as the type species of the genus. A fourth member of the genus, Cellulophaga algicola, which originated from the surface of algal species from Antarctic marine coasts and sea ice, was described relatively recently (Bowman, 2000). This author also reclassified [Cytophaga]

Published online ahead of print on 31 October 2003 as DOI 10.1099/ ijs.0.02737-0.

Abbreviations: ACAM, Australian Collection of Antarctic Microorganisms, University of Tasmania, Hobart, Tasmania, Australia; ATCC, American Type Culture Collection, Manassas, VA, USA; JCM, Japan Collection of Microorganisms, Institute of Physical and Chemical Research (RIKEN), Wako, Japan; KMM, Collection of Marine Microorganisms of the Pacific Institute of Bioorganic Chemistry of the Far-Eastern Branch of the Russian Academy of Sciences, Vladivostok, Russia; LMG, BCCM/LMG Bacteria Collection, Laboratorium Microbiologie, Universiteit Gent, Belgium; NN, Enzyme Research, Novo Nordisk A/S, Bagsvaerd, Denmark.

The GenBank/EMBL/DDBJ accession numbers for the 16S rDNA sequences of Cellulophaga pacifica KMM $3664^{\top}, \mathrm{KMM} 3669$ and KMM 3915 are $A B 100840, A B 100841$ and $A B 100842$, respectively. uliginosa (Reichenbach, 1989), formerly Flavobacterium uliginosum (ZoBell \& Upham, 1944), in the genus Cellulophaga as Cellulophaga uliginosa. Recently, C. uliginosa has been transferred to a novel genus, Zobellia, based on DNA $\mathrm{G}+\mathrm{C}$ content, maximum growth temperature, presence of flexirubin and phylogenetic position (Barbeyron et al., 2001).

Three gliding, agarolytic, strictly aerobic, Gram-negative and yellow-pigmented bacterial strains were isolated from a sea water sample that was collected in the Sea of Japan, Pacific Ocean. Phenotypic, chemotaxonomic and genotypic characteristics assigned these bacteria to the family Flavobacteriaceae. Phylogenetic and phenotypic data indicated that the unknown organisms comprised a distinct species within the genus Cellulophaga. The name Cellulophaga pacifica sp. nov. is proposed for these sea water isolates; the type strain is KMM $3664^{\mathrm{T}}\left(=\mathrm{JCM} 11735^{\mathrm{T}}=\mathrm{LMG} 21938^{\mathrm{T}}\right)$.

Strains KMM 3664 ${ }^{\mathrm{T}}$, KMM 3669 and KMM 3915 were isolated from a sea water sample that was collected during June 2000 in Amursky Bay, Gulf of Peter the Great, Sea of Japan, Pacific Ocean, from a depth of $5 \mathrm{~m}$ (salinity, $33 \%$; temperature, $15^{\circ} \mathrm{C}$ ). After primary isolation and purification, strains were cultivated at $28^{\circ} \mathrm{C}$ on marine agar 2216 (Difco) and stored at $-80^{\circ} \mathrm{C}$ in marine broth (Difco) supplemented with $20 \%(\mathrm{v} / \mathrm{v})$ glycerol. The bacteria isolated in this study and reference strains are shown in Table 1. 
Table 1. Bacterial strains used in this study

\begin{tabular}{|ll|}
\hline Taxon and strain & \multicolumn{1}{c|}{ Isolation source and location } \\
\hline $\begin{array}{l}\text { Cellulophaga pacifica: } \\
\text { KMM } 3664^{\mathrm{T}}\end{array}$ & Sea water, Sea of Japan, Pacific Ocean \\
KMM 3669 & Sea water, Sea of Japan, Pacific Ocean \\
KMM 3915 & Sea water, Sea of Japan, Pacific Ocean \\
Cellulophaga lytica ATCC $23178^{\mathrm{T}}$ & Beach mud, Costa Rica, Pacific Ocean \\
Cellulophaga fucicola NN015860 & Brown alga Fucus serratus, North Sea, Atlantic Ocean \\
Cellulophaga baltica NN015840 & Brown alga Fucus serratus, North Sea, Atlantic Ocean \\
Cellulophaga algicola ACAM $630^{\mathrm{T}}$ & Alga from marine coast and sea ice, Antarctica \\
\hline
\end{tabular}

To detect the precise taxonomic position of the strains studied, the almost-complete $16 \mathrm{~S}$ rDNA sequences of strains KMM $3664^{\mathrm{T}}$, KMM 3669 and KMM 3915 were determined by PCR amplification and direct sequencing (Hiraishi, 1992), using conditions and reagents that were described previously (Suzuki et al., 2001). The determined sequences were aligned to an alignment based on a secondary structure model, maintained by the SSU rRNA database (Van de Peer et al., 2000), by using the profile alignment program of the CLUSTAL $\mathrm{W}$ software (Thompson et al., 1994). Evolutionary distances were then computed with the DNADIST program in the PHYLIP 3.572 package (Felsenstein, 1995) with the Kimura two-parameter correction (Kimura, 1980); a phylogenetic tree was constructed by using the neighbour-joining method (Saitou \& Nei, 1987). To evaluate the phylogenetic tree, bootstrap analysis with 1000 sample replications was performed with the SEQBOOT and CONSENSE programs in the PHYLIP 3.572 package.

Comparative analysis of the sequences obtained in this study with published sequences of representatives of the phylum Cytophaga-Flavobacterium-Bacteroides that have been described to date revealed that the sea water isolates were members of the family Flavobacteriaceae and formed a distinct lineage within the genus Cellulophaga (Fig. 1). 16S rDNA sequence similarity values of strains KMM $3664^{\mathrm{T}}$, KMM 3669 and KMM 3915 to the type strains of C. lytica and C. fucicola were too low $(91 \cdot 9-92 \cdot 1$ and $93 \cdot 0-93 \cdot 1 \%$, respectively) to consider the new isolates as members of these species. However, the new isolates shared a level of $16 \mathrm{~S}$ rDNA sequence similarity that may indicate possible species-level relatedness to the type strains of $C$. algicola and C. baltica $(97 \cdot 1$ and $97 \cdot 5 \%$, respectively).

For determination of DNA G $+\mathrm{C}$ content and DNA-DNA binding values, DNA was prepared from cells that had been cultivated on marine agar (Difco) for $24-48 \mathrm{~h}$ at $25^{\circ} \mathrm{C}$. The DNA G $+\mathrm{C}$ content was determined by using two approaches: (i) the thermal denaturation method of Marmur \& Doty (1962) for strains KMM $3664^{\mathrm{T}}$, KMM 3669 and KMM 3915, using the DNA extraction protocol of Marmur (1961); and (ii) the HPLC method of Mesbah et al. (1989) for C. baltica NN015840 ${ }^{\mathrm{T}}$, KMM $3664^{\mathrm{T}}$ and

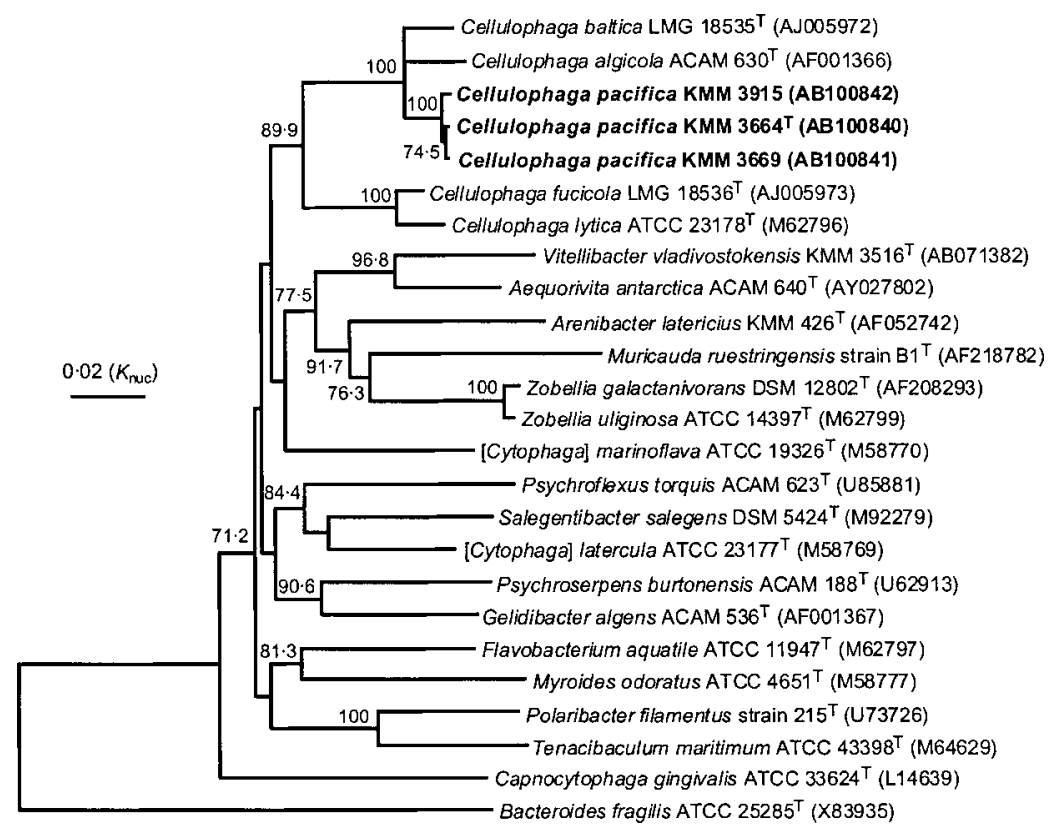

Fig. 1. Phylogenetic position of strains KMM $3664^{\top}$, KMM 3669 and KMM 3915 among species of the family Flavobacteriaceae on the basis of $16 \mathrm{~S}$ rDNA sequence comparison. The phylogenetic tree was generated by the neighbour-joining method (Saitou \& Nei, 1987). The 16S rDNA sequence of Bacteroides fragilis (GenBank accession no. X83935) was used as the outgroup. Numbers next to nodes indicate percentage bootstrap values from 1000 replicates (only values of $70 \%$ or higher are cited). Bar, 0.02 genetic distance $\left(K_{\text {nuc }}\right)$. 
KMM 3669, following the DNA extraction protocol of Pitcher et al. (1989) as modified by Leisner et al. (2002) and, for C. algicola ACAM $630^{\mathrm{T}}$, by using the DNA extraction protocol of Wilson (1987) as modified by Cleenwerck et al. (2002). These high-molecular-mass DNA extracts were used to perform DNA-DNA hybridizations, using the microplate method and fluorescence measurements for calculation of binding values as described by Ezaki et al. (1989). Hybridizations were performed at $35^{\circ} \mathrm{C}$ in hybridization mixture $(2 \times$ SSC, $5 \times$ Denhardt's solution, $2.5 \%$ dextran sulphate, $50 \%$ formamide, $100 \mu \mathrm{g}$ denaturated salmon sperm DNA ml ${ }^{-1}, 1250 \mathrm{ng}$ biotinylated probe DNA ml${ }^{-1}$ ).

DNA-DNA hybridization experiments indicated that strains KMM $3664^{\mathrm{T}}$, KMM 3669 and KMM 3915 shared only 11$12 \%$ DNA-DNA homology with C. baltica NN $015840^{\mathrm{T}}$ and C. algicola ACAM $630^{\mathrm{T}}$. Furthermore, the three new isolates represented one genomic group, with DNA-DNA binding values of $72-90 \%$ between them. DNA-DNA relatedness between $C$. algicola and C. baltica was $32 \%$; this confirms the results of Bowman (2000). DNA G+C contents were $33 \cdot 2,33 \cdot 0$ and $34 \cdot 3 \mathrm{~mol} \%$ for strains KMM $3664^{\mathrm{T}}, \mathrm{KMM} 3669$ and $\mathrm{KMM}$ 3915, respectively, when determined by the thermal denaturation method. Slightly lower values of $31 \cdot 6,32 \cdot 0,33 \cdot 4$ and $34 \cdot 6 \mathrm{~mol} \%$ for KMM $3664^{\mathrm{T}}, \mathrm{KMM} 3669$, C. algicola ACAM $630^{\mathrm{T}}$ and C. baltica $\mathrm{NN} 015840^{\mathrm{T}}$, respectively, were observed when determined by HPLC.

For determination of whole-cell fatty acid composition, strains were cultivated at $21^{\circ} \mathrm{C}$ for $48 \mathrm{~h}$ on marine agar 2216 (Difco). Analysis of fatty acid methyl esters was performed by GLC [ $30 \mathrm{~m} \times 0.25 \mathrm{~mm}$ Supelcowax 10 column, $\left.205^{\circ} \mathrm{C}\right]$ as described by Svetashev et al. (1995).

The predominant cellular fatty acids of strains KMM $3664^{\mathrm{T}}$, KMM 3669 and KMM 3915 were branched-chain saturated and unsaturated fatty acids and straight-chain saturated and monounsaturated fatty acids, namely i- $\mathrm{C}_{15: 0}$ (9.1, 6.1 and $9 \cdot 6 \%$, respectively), $\mathrm{i}-\mathrm{C}_{15: 1}(20 \cdot 9,13 \cdot 1$ and $19 \cdot 6 \%$, respectively), $\mathrm{C}_{15: 0}(16 \cdot 6,12 \cdot 0$ and $16 \cdot 9 \%$, respectively), $\mathrm{C}_{16: 1} \omega 7(13 \cdot 3,9 \cdot 1$ and $17 \cdot 4 \%$, respectively) and i- $\mathrm{C}_{17: 0} 3-\mathrm{OH}(3 \cdot 7,7 \cdot 8$ and $2 \cdot 8 \%$, respectively). Isoprenoid quinones were extracted and analysed by the method of Nakagawa \& Yamasato (1993). The major lipoquinone was MK-6. The results of chemotaxonomic analyses support the affiliation of the sea water isolates to the family Flavobacteriaceae, all members of which are characterized by the presence of menaquinone 6 as the only or major respiratory quinone and the predominance of fatty acids $\mathrm{C}_{15: 0}, \mathrm{i}-\mathrm{C}_{15: 0}$ and $\mathrm{i}-\mathrm{C}_{17: 0} 3-\mathrm{OH}$ (Bernardet et al., 1996, 2002).

Gram-staining reaction, oxidase, catalase and alkaline phosphatase activities, degradation of agar, starch, casein, gelatin, cellulose (filter paper and CM-cellulose), chitin, DNA, Tweens 20, 40 and 80, urea and alginic acids, flexirubin production, growth at different temperatures, $\mathrm{NaCl}$ concentrations and $\mathrm{pH}$, production of acid from carbohydrates, nitrate reduction and production of $\mathrm{H}_{2} \mathrm{~S}$, indole and acetoin (Voges-Proskauer reaction) were tested according to the methods of Gerhardt et al. (1994). Susceptibility to antibiotics was determined as described previously (Nedashkovskaya et al., 2003). Gliding motility and spreading growth were determined by cultivation of strains on a medium that contained $\left(\mathrm{l}^{-1}\right): 1 \mathrm{~g}$ Bactopeptone (Difco), $1 \mathrm{~g}$ yeast extract (Difco), $15 \mathrm{~g}$ agar and halfstrength artificial sea water. The results are summarized in Table 2 and in the species description (see below).

Strains KMM $3664^{\mathrm{T}}$, KMM 3669 and KMM 3915 have some traits in common with currently described Cellulophaga species, but can be differentiated from all of them by arabinose and raffinose oxidation and the absence of DNase production, alginate hydrolysis and susceptibility to carbenicillin. The strains do not grow at $37^{\circ} \mathrm{C}$, in contrast to C. lytica strains. Reduction of nitrates to nitrites is noted for the strains studied, but not for strains of $C$. lytica or C. fucicola. Strains KMM $3664^{\mathrm{T}}$, KMM 3669 and KMM 3915 differ from the type strains of C. baltica $\left(\mathrm{NN} 015840^{\mathrm{T}}\right)$ and C. fucicola $\left(\mathrm{NN} 015860^{\mathrm{T}}\right)$ by the absence of casein hydrolysis.

Based on the results of the polyphasic taxonomic analysis that is presented in this work, the new environmental isolates clearly represent a novel species in the genus Cellulophaga. We propose that strains KMM $3664^{\mathrm{T}}$, KMM 3669 and KMM 3915 should be placed in this genus as members of a novel species, Cellulophaga pacifica sp. nov.

\section{Description of Cellulophaga pacifica sp. nov.}

Cellulophaga pacifica (pa.ci'fi.ca. N.L. adj. pacifica still; referring to the Pacific Ocean, from which the organism was isolated).

Cells are Gram-negative, strictly aerobic, chemo-organotrophic, motile by gliding, asporogenic rods that are $0 \cdot 5-0 \cdot 7 \mu \mathrm{m}$ wide and $2 \cdot 7-5 \cdot 3 \mu \mathrm{m}$ long. Oxidase-, catalaseand alkaline phosphatase-positive. Colonies are circular, low convex, shiny with entire edges, weakly sunken into agar and 1-3 mm in diameter on marine agar 2216. Yellow, non-diffusible pigments are produced. No growth is observed without $\mathrm{Na}^{+}$. Growth occurs at $1-8 \% \mathrm{NaCl}$. $\mathrm{pH}$ range for growth is $5 \cdot 5-10 \cdot 0$, with optimum growth at $\mathrm{pH} 7 \cdot 5-8 \cdot 5$. Flexirubin pigments are absent. Growth is detected at 4 and $34^{\circ} \mathrm{C}$. Agar, gelatin, starch and Tweens 20, 40 and 80 are hydrolysed, but casein, cellulose (CMcellulose and filter paper), alginic acids, chitin and DNA are not. Nitrate reduction is positive. Indole, acetoin (Voges-Proskauer reaction) and $\mathrm{H}_{2} \mathrm{~S}$ are not produced. Acid is formed from arabinose, cellobiose, galactose, glucose, lactose, maltose, raffinose, sucrose and xylose, but not from melibiose, rhamnose, sorbose, $\mathrm{N}$-acetylglucosamine, adonitol, dulcitol, glycerol, inositol, sorbitol or mannitol. Strains are susceptible to carbenicillin, oleandomycin and lincomycin and resistant to kanamycin, benzylpenicillin, neomycin, tetracycline, gentamicin and polymyxin $\mathrm{B}$. 
Table 2. Phenotypic properties of Cellulophaga pacifica and other Cellulophaga species

Strains: 1, C. pacifica KMM 3664 ${ }^{\mathrm{T}}$; 2, C. pacifica KMM 3669; 3, C. pacifica KMM 3915; 4, C. lytica ATCC 23178 ${ }^{\mathrm{T}}$; 5, C. algicola ACAM $630^{\mathrm{T}} ; 6$, C. baltica $\mathrm{NN} 015840^{\mathrm{T}} ; 7$, C. fucicola NN015860 ${ }^{\mathrm{T}}$. Data are from Johansen et al. (1999), Bowman (2000) and this study. All strains tested were positive for the following characteristics: motion by gliding, respiratory metabolism, oxidase, catalase and alkaline phosphatase production, $\mathrm{Na}^{+}$requirement for growth, growth at $4{ }^{\circ} \mathrm{C}$, growth at $6 \% \mathrm{NaCl}$, hydrolysis of agar, gelatin and starch and susceptibility to lincomycin and oleandomycin. All strains were negative for the following characteristics: flexirubin pigments, growth at $10 \% \mathrm{NaCl}$, hydrolysis of cellulose (CM-cellulose and filter paper) and chitin, production of $\mathrm{H}_{2} \mathrm{~S}$, indole and acetoin (Voges-Proskauer reaction), acid from rhamnose, sorbose, $\mathrm{N}$-acetylglucosamine, adonitol, dulcitol, glycerol, inositol and sorbitol and susceptibility to benzylpenicillin, gentamicin, kanamycin and neomycin.

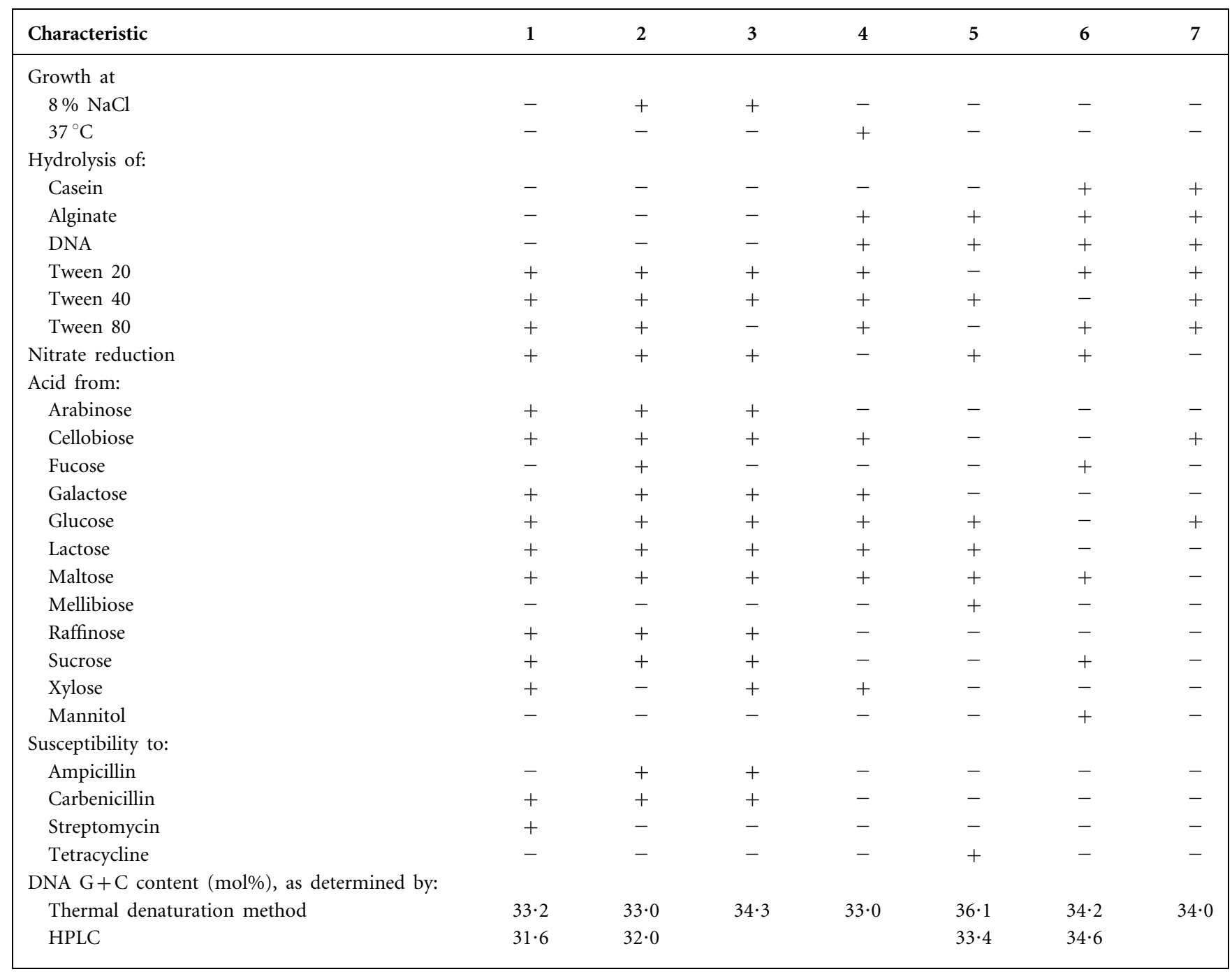

Predominant cellular fatty acids are $\mathrm{i}-\mathrm{C}_{15: 0}, \mathrm{i}-\mathrm{C}_{15: 1}, \mathrm{C}_{15: 0}$, $\mathrm{C}_{16: 1} \omega 7$ and $\mathrm{i}-\mathrm{C}_{17: 0} 3-\mathrm{OH}$. Major lipoquinone is MK-6. DNA $\mathrm{G}+\mathrm{C}$ content is $32-34 \mathrm{~mol} \%$ ( $T_{\mathrm{m}}$ and HPLC).

The type strain is $\mathrm{KMM} 3664^{\mathrm{T}}\left(=\mathrm{JCM} 11735^{\mathrm{T}}=\mathrm{LMG}\right.$ $\left.21938^{\mathrm{T}}\right)$. Isolated from sea water.

\section{Acknowledgements}

We are deeply grateful to Drs Preben Nielsen from Enzyme Research, Novo Nordisk A/S, Denmark, and Carol Mancuso Nichols from the Australian Collection of Antarctic Microorganisms, University of
Tasmania, Australia, for providing us with C. baltica $\mathrm{NN} 015840^{\mathrm{T}}, C$. fucicola $\mathrm{NN} 015860^{\mathrm{T}}$ and C. algicola ACAM $630^{\mathrm{T}}$, respectively, for use in this study. This research was supported by grant no. 03-19 from the Ministry for Industry, Science and Technologies of the Russian Federation and grant no. 02-04-49517 from the Russian Foundation for Basic Research.

\section{References}

Barbeyron, T., L'Haridon, S., Corre, E., Kloareg, B. \& Potin, P. (2001). Zobellia galactanovorans gen. nov., sp. nov., a marine species of Flavobacteriaceae isolated from a red alga, and classification of [Cytophaga] uliginosa (ZoBell and Upham 1944) Reichenbach 1989 as 
Zobellia uliginosa gen. nov., comb. nov. Int J Syst Evol Microbiol 51, 985-997.

Bernardet, J.-F., Segers, P., Vancanneyt, M., Berthe, F., Kersters, K. \& Vandamme, P. (1996). Cutting a Gordian knot: emended classification and description of the genus Flavobacterium, emended description of the family Flavobacteriaceae, and proposal of Flavobacterium hydatis nom. nov. (basonym, Cytophaga aquatilis Strohl and Tait 1978). Int J Syst Bacteriol 46, 128-148.

Bernardet, J.-F., Nakagawa, Y. \& Holmes, B. (2002). Proposed minimal standards for describing new taxa of the family Flavobacteriaceae and emended description of the family. Int J Syst Evol Microbiol 52, 1049-1070.

Bowman, J. P. (2000). Description of Cellulophaga algicola sp. nov., isolated from the surfaces of Antarctic algae, and reclassification of Cytophaga uliginosa (ZoBell and Upham 1944) Reichenbach 1989 as Cellulophaga uliginosa comb. nov. Int J Syst Evol Microbiol 50, 1861-1868.

Cleenwerck, I., Vandemeulebroecke, K., Janssens, D. \& Swings, J. (2002). Re-examination of the genus Acetobacter, with descriptions of Acetobacter cerevisiae sp. nov. and Acetobacter malorum sp. nov. Int J Syst Evol Microbiol 52, 1551-1558.

Ezaki, T., Hashimoto, Y. \& Yabuuchi, E. (1989). Fluorometric deoxyribonucleic acid-deoxyribonucleic acid hybridization in microdilution wells as an alternative to membrane filter hybridization in which radioisotopes are used to determine genetic relatedness among bacterial strains. Int J Syst Bacteriol 39, 224-229.

Felsenstein, F. (1995). PHYLIP (Phylogeny Inference Package) version 3.57c. Seattle: University of Washington.

Gerhardt, P., Murray, R. G. E., Wood, W. A. \& Krieg, N. R. (editors) (1994). Methods for General and Molecular Bacteriology. Washington, DC: American Society for Microbiology.

Hiraishi, A. (1992). Direct automated sequencing of $16 \mathrm{~S}$ rDNA amplified by polymerase chain reaction from bacterial cultures without DNA purification. Lett Appl Microbiol 15, 210-213.

Johansen, J. E., Nielsen, P. \& Sjøholm, C. (1999). Description of Cellulophaga baltica gen. nov., sp. nov. and Cellulophaga fucicola gen. nov., sp. nov. and reclassification of [Cytophaga] lytica to Cellulophaga lytica gen. nov., comb. nov. Int J Syst Bacteriol 49, 1231-1240.

Kimura, M. (1980). A simple method for estimating evolutionary rates of base substitutions through comparative studies of nucleotide sequences. J Mol Evol 16, 111-120.

Leisner, J. J., Vancanneyt, M., Lefebvre, K., Vandemeulebroecke, K., Hoste, B., Euras Vilalta, N., Rusul, G. \& Swings, J. (2002). Lactobacillus durianis sp. nov., isolated from an acid-fermented condiment (tempoyak) in Malaysia. Int J Syst Evol Microbiol 52, 927-931.

Lewin, R. A. (1969). A classification of flexibacteria. J Gen Microbiol 58, 189-206.
Marmur, J. (1961). A procedure for the isolation of deoxyribonucleic acid from microorganisms. J Mol Biol 3, 208-218.

Marmur, J. \& Doty, P. (1962). Determination of the base composition of deoxyribonucleic acid from its thermal denaturation temperature. J Mol Biol 5, 109-118.

Mesbah, M., Premachandran, U. \& Whitman, W. B. (1989). Precise measurement of the $\mathrm{G}+\mathrm{C}$ content of deoxyribonucleic acid by high-performance liquid chromatography. Int J Syst Bacteriol 39, 159-167.

Nakagawa, Y. \& Yamasato, K. (1993). Phylogenetic diversity of the genus Cytophaga revealed by $16 \mathrm{~S}$ rRNA sequencing and menaquinone analysis. J Gen Microbiol 139, 1155-1161.

Nedashkovskaya, O. I., Suzuki, M., Vysotskii, M. V. \& Mikhailov, V. V. (2003). Reichenbachia agariperforans gen. nov., sp. nov., a novel marine bacterium in the phylum Cytophaga-FlavobacteriumBacteroides. Int J Syst Evol Microbiol 53, 81-85.

Pitcher, D. G., Saunders, N. A. \& Owen, R. J. (1989). Rapid extraction of bacterial genomic DNA with guanidium thiocyanate. Lett Appl Microbiol 8, 151-156.

Reichenbach, H. (1989). Genus I. Cytophaga Winogradsky 1929, 577, ${ }^{\mathrm{AL}}$ emend. In Bergey's Manual of Systematic Bacteriology, vol. 3, pp. 2015-2050. Edited by J. T. Staley, M. P. Bryant, N. Pfennig \& J. C. Holt. Baltimore: Williams \& Wilkins.

Saitou, N. \& Nei, M. (1987). The neighbor-joining method: a new method for reconstructing phylogenetic trees. Mol Biol Evol 4, 406-425.

Suzuki, M., Nakagawa, Y., Harayama, S. \& Yamamoto, S. (2001). Phylogenetic analysis and taxonomic study of marine Cytophaga-like bacteria: proposal for Tenacibaculum gen. nov. with Tenacibaculum maritimum comb. nov. and Tenacibaculum ovolyticum comb. nov., and description of Tenacibaculum mesophilum sp. nov. and Tenacibaculum amylolyticum sp. nov. Int J Syst Evol Microbiol 51, 1639-1652.

Svetashev, V. I., Vysotskii, M. V., Ivanova, E. P. \& Mikhailov, V. V. (1995). Cellular fatty acids of Alteromonas species. Syst Appl Microbiol 18, 37-43.

Thompson, J. D., Higgins, D. G. \& Gibson, T. J. (1994). CLUSTAL W: improving the sensitivity of progressive multiple sequence alignment through sequence weighting, position-specific gap penalties and weight matrix choice. Nucleic Acids Res 22, 4673-4680.

Van de Peer, Y., De Rijk, P., Wuyts, J., Winkelmans, T. \& De Wachter, R. (2000). The European small subunit ribosomal RNA database. Nucleic Acids Res 28, 175-176.

Wilson, K. (1987). Preparation of genomic DNA from bacteria. In Current Protocols in Molecular Biology, pp. 241-245. Edited by F. M. Ausubel, R. Brent, R. E. Kingston, D. D. Moore, J. G. Seidman, J. A. Smith \& K. Struhl. New York: Greene Publishing and Wiley.

ZoBell, C. E. \& Upham, H. C. (1944). A list of marine bacteria including descriptions of sixty new species. Bull Scripps Inst Oceanogr Univ Calif 5, 239-292. 